\title{
Ação Antimicrobiana de Óleo de Orégano e Nanopartícula de Prata Combinados Frente à Staphylococcus aureus
}

\author{
Sara Scandorieiro (I), Giovana Carolina Bodnar (I), Renata Katsuko \\ Takayama Kobayashi (I), Gerson Nakazato (I) \\ (I) UEL - Universidade Estadual de Londrina (Rodovia Celso Garcia Cid Pr 445, Km 380. Cx \\ Postal 10011)
}

\section{Resumo}

Devido ao surgimento de micro-organismos resistentes às drogas convencionais, tem sido intensa a busca pela descoberta e desenvolvimento de novos agentes antimicrobianos. Uma alternativa é a pesquisa com compostos produzidos por plantas; estudos com óleos essenciais mostram que o óleo de orégano apresenta atividade antimicrobiana eficiente, principalmente inibindo o crescimento de bactérias associadas à contaminação de alimentos e às doenças infecciosas como Staphylococcus aureus. Nanopartículas (NP) também tem sido uma opção atrativa de antimicrobianos porque tem amplo espectro de ação antibacteriana mesmo em baixa concentração, NPs de prata possuem atividade bactericida contra bactérias Gram negativas e positivas, incluindo linhagens multirresistentes. O objetivo deste trabalho foi avaliar o efeito antimicrobiano do óleo de orégano e NP de prata combinados frente à Staphylococcus aureus ATCC 6538. Foi realizado o teste de microdiluição em caldo, de acordo com CLSI, para determinar a concentração inibitória mínima (CIM) do óleo e da prata separadamente. Posteriormente, o efeito antimicrobiano da combinação dos dois compostos foi testado através do método de microdiluição "checkerboard". Para avaliar a interação dos compostos foi calculada a concentração inibitória fracionada (FIC). As CIMs do óleo de orégano e da NP de prata separados foram $0,5 \%$ (v/v) e $125 \mu \mathrm{M}$ respectivamente, e quando combinados as CIMs do óleo caiu para $0,125 \%$

\footnotetext{
Referência:

Sara Scandorieiro, Giovana Carolina Bodnar, Renata Katsuko Takayama Kobayashi, Gerson Nakazato. Ação Antimicrobiana de Óleo de Orégano e Nanopartícula de Prata Combinados Frente à Staphylococcus aureus. In: Anais do $12^{\circ}$ Congresso Latinoamericano de Microbiologia e Higiene de Alimentos - MICROAL 2014 [= Blucher Food Science Proceedings, num.1, vol.1]. São Paulo: Editora Blucher, 2014. DOI 10.5151/foodsci-microal-321
} 
(v/v) e da NP de prata para $31,25 \mu \mathrm{M}$. A FIC da combinação foi 0,5 ; interpreta-se como sinergismo quando FIC $\leq 0,5$ e como aditismo quando $0,5<\mathrm{FIC} \leq 1,0$. Este experimento mostrou que a interação entre o óleo do orégano com a NP de prata fica no limite entre sinergismo e aditismo; portanto, os compostos tem seus efeitos potencializados ou somados, considerando a ocorrência de interação sinérgica ou aditismo respectivamente. A utilização da terapia combinada é uma estratégia para evitar o surgimento de resistência; além disso, o óleo de orégano e a NP de prata combinados podem ser utilizados na indústria alimentícia (incorporados em embalagens ou em cápsulas na forma de gel para retardar o envelhecimento de frutas e outros alimentos) ou até permitir o controle microbiano em produtos farmacêuticos como curativos e pomadas.

Palavras-Chave: Micro-organismos, Nanopartículas de prata, Óleo de orégano

Agência de Fomento: $\mathrm{CNPq}$ 